\title{
Regional Development Based on System Integration Paddy Rice Farming and Livestock Buffaloes in Humbang Hasundutan Regency
}

\author{
Hotden L. Nainggolan ${ }^{1,2}$ ), Marlon Sihombing ${ }^{3}$ ), Tavi Supriana ${ }^{4}$ ), Ma'ruf Tafsin ${ }^{5}$ ) \\ $\left.{ }^{1}\right)$ Doctoral Student in Regional Planning Graduate School of \\ Universitas Sumatera Utara. email: hotden_ngl@yahoo.com \\ $\left.{ }^{2}\right)$ Agribusiness Studies Program Faculty of Agriculture, HKBP Nommensen University. \\ $\left.{ }^{3}\right)$ Social and Political Sciences Faculty of the University of North Sumatera. \\ email: mrlnsihombing@gmail.com \\ $\left.{ }^{4}\right)$ Agribusiness Studies Program Faculty of Agriculture, University of North Sumatera. \\ email: tavihutasuhut@yahoo.co.id \\ $\left.{ }^{5}\right)$ Animal Husbandry Program Faculty of Agriculture, University of North Sumatera.
}

\begin{abstract}
This study was conducted to assess the regional development based on system integration paddy rice farming and livestock buffaloes in Humbang Hasundutan. This study uses analysis of linear regression with SPSS. The results showed; a) system integration paddy rice farming and livestock buffaloes more efficient than non-integration farming, with a value of $\mathrm{R} / \mathrm{C}$ ratio of paddy raice and buffaloes in integration farming is $2.4795>\mathrm{R} / \mathrm{C}$ ratio of non integration farming, b) physical factors such as system integration farming that variable; land area, livestock breeds, and livestock seeds have a positive and significant impact to regional development, c) social factors is a variable system integration farming that variable; labor and the level of education farmers have a positive and significant impact to regional development, while social variables; dependents of farmers have a negative effect to regional development, d) economic factors such as variable system integration; capital of farming and output prices have a positive effect and significant to regional development, while the variable input prices a negatife affect to regional development. Based on the research results suggested: a) the government of Humbang Hasundutan training the farmers in managing systems integration paddy rice and livestock, b) the government of Humbang Hasundutan provide quality seeds and reasonably priced, and counseling about how to make a good farming, c) the government of Humbang Hasundutan providing education and training to improve traffic farmers to development farming which increased revenue to regional development, d) the government of Humbang Hasundutan helped farmers to obtain capital more flexible farming and should maintain the stability of output prices of agricultural products.
\end{abstract}

Keywords-integrated farming system; paddy rice; buffaloes; revenue; regional development.

\section{INTRODUCTION}

The agricultural sector has an important role in the national economic development and has an important role as the main employer, producer of the staple food, agricultural commodities as a determinant of price stability, the driving exports and agricultural commodities as material manufacturing industry. Regional development is a development process that is intended to make a change towards a better development for communities, governments, and environment in the region by utilizing a variety of resources such as agriculture sector (Riyadi and Baratakusumah, 2003).

Development of the agricultural sector can be done in various policies, including the development of technology in agriculture and agribusiness. Gumbira (2001) in Juangsana (2013) convey the technological development in agriculture and agribusiness is expected to be one important factor in the development of agriculture that contributes to; a) increase productivity and efficiency; b) introduce appropriate new technologies, c) provide added value.

Agricultural development can be done through intensification, extension, diversification, and rehabilitation in an integrated manner with the aim to increase farmers' income. Agricultural development to increase farmers' income can be done with a variety of approaches that have relevance to physical factors, namely; land use, fertilizer, seed, plant cultivation, plant protection. Social factors such as; labor, farmer education and institutional level. Economic factors such as; capital, farmers income, interest rates, inflation 
and the form factor of development, roads, and irrigation (Nainggolan at al, 2016).

Diabel et al., (2008), said that physical factors such as; fertility of soil, topography, land use, and social factors such as; management activities of farmers and shape affect the productivity of up to $10 \%$ of the farms are managed. Boix and Zinck (2008) also expressed over the planning of physical factors, namely; good land use affect monoculture farming systems for food commodities, helping farmers may use the land effectively.

In the framework of agricultural development, the government has made agricultural development policies with the aim of increasing the capacity of farmers through agricultural development, namely the formulation of objectives; a) increase the income and standard of living of farmers through the development of agribusiness systems, b) develop activities competitive agribusiness and sustainable, c) to realize the food security system that is based on the diversity of food and local food cultures, d) increasing job opportunities and businesses for society through the development of agribusiness (Setyowati, 2012).

The agricultural sector has an important role in people's income and development of Humbang Hasundutan Regency because the agricultural sector contributes significantly to GDP region. The agricultural sector contributed $52.79 \%$ (in The year 2012), and 53.6\% (inYear 2014) to the GDP Humbang Hasundutan Regency, with an average growth rate of $3.83 \%$ for 2009-2014 (BPS, Humbang Hasundutan Dalam Angka, 2015).

Agus (2006); Ugwumba (2010), said the integrated farming system (IFS) was able to improve the productivity of rice farming and improve the income of farmers. Rice production can be increased from the usual 5-6 tonnes/ hectare up to 7.6 to 8 tons/ hectare. Chili productivity can be increased from $0.5 \mathrm{~kg} / \mathrm{plant}$ up to $0.7 \mathrm{~kg} / \mathrm{plant}$ (Nurcholish, 2011), even the integrated farming system (IFS) is more reliable if the constituent components is a local resource (Salikin, 2003).

Preston (2000) says the integrated farming system (IFS) is a management system of the crop, livestock, and fish with the environment to produce a product optimally. Sutanto (2002); Supangkat (2009), delivering an integrated farming system (IFS) has the advantage both in terms of ecological and economic aspects, namely; farming is environmentally friendly, energy efficient, more diversification of farming, diversification of products higher and better labor absorption (Nainggolan at al, 2016).

Humbang Hasundutan as a potential area for development of the agricultural sector, there are farmers to cultivate paddy rice commodity that is integrated with the livestock with a total 8,937 households. Farming is managed by the concept of agricultural integration between paddy rice farming as a core business with livestock buffaloes in household scale and spread in 10 districts. This system is a farm managed by the farmers for generations as a local wisdom. This farm work force in families with limited capital, with management scheme by local wisdom (Nainggolan at al, 2016).

BPS (2014) show that the rate of growth of productivity of commodity paddy rice on Humbang Hasudutan fluctuated 2009-2012. Year 2009 recorded $1.0 \%$, rising to $1.48 \%$ in 2010 and fell to $0.10 \%$ in 2011 and rose to $0.60 \%$ in 2012 , with an average growth rate of $0.80 \%$ and smaller than the average rate of growth of productivity of paddy rice is $2.14 \%$ of North Sumatera (BPS Sumatera Utara, 2014), thus the much needed agricultural development planning to improve agricultural productivity and more comprehensive agricultural development in accordance with the potential and agro-ecological conditions of the region in order increase the income of farmers in Humbang Hasundutan Regency.

Elizabeth and Darwis (2003) stated there are some things that the strength of the farmers in increasing their income, namely; a) motivation owned by farmers in farming rice and the desire of farmers to increase their income, b) experience of farmers to manage rice farming, c) availability of labor in the family to process the farming, d) marketing that is easy for the product of farm, for example, consumers come to the location of the farm to buy the product of farmers. Furthermore Yanti, et all (2010) convey some internal factors that affect farmers' income increase in paddy rice, namely; a) access to capital for farmers needs of the means of production factors, b) ease of getting quality seeds and fertilizers, c) the economic value of rice and good marketing for the revenue farmers. Based on the above research is conducted to assess the regional development based on system integration paddy rice and livestock buffaloes in Humbang Hasundutan Regency.

\section{RESEARCH PURPOSES}

Based on the background described, the goal of this research is:

1. To determine the efficiency of system integration paddy rice farming and livestock buffaloes and non-integration in Humbang Hasundutan Regency.

2. To determine the influence of physical factors, namely; land area, paddy rice seeds, livestock breeds, livestock feeds, paddy rice fertilizer and pesticide in the system integration paddy 
rice farming and livestock buffaloes to the regional development in Humbang Hasundutan Regency.

3. To determine the influence of social factors, namely; labor, education of farmer, dependent of farmers in the system integration of paddy rice farming and livestock buffaloes to the regional development in Humbang Hasundutan Regency.

4. To determine the influence of economic factors, namely; farm capital, input prices, output prices in the system integration paddy rice farming and livestock buffaloes to the regional development in Humbang Hasundutan Regency.

\section{RESEARCH METHODS}

This research was conducted in Humbang Hasundutan, determined purposive as well as this region is an agricultural area with the potential to be developed in the framework of regional development.

The population in this study were farmers paddy rice farming with livestock buffaloes in the scale of households by 8,937 , spread over 10 districts in Humbang Hasundutan, there are District of Pakkat (1,663 households), Onan Ganjang (708 households), Sijamapolang (233 households), Doloksanggul (1,456 households), Lintong Nihuta (1,150 households), Paranginan (560 households), Baktiraja (152 households), Pollung (1,242 households), Parlilitan (1,342 households) and Tarabintang (428 households), (BPS Humbang Hasundutan, 2015), The sample in this study was determined by using a formula Slovin;

$$
n_{c}=\frac{N}{1+N e^{2}}
$$

Where; ${ }_{\mathrm{c}} \mathrm{NC}=$ sample size, $\mathrm{e}=$ interval error $(0.1)$, $\mathrm{N}=$ Population. The samples obtained are rounded 99.98 up to 100 samples. Total sample (respondents) who will be interviewed for each district is determined in proportion to the sampling method is purposive (Sugiyono, 2006), with the details; District of Pakkat (19 respondents), Onan Ganjang (8 respondents), Sijamapolang (3 respondents), Doloksanggul (16 respondents), Lintong Nihuta (13 respondents), Paranginan (6 respondents), Baktiraja (2 respondents), Polling (14 respondents), Parlilitan (15 respondents) and Tarabintang (5 respondents).

\section{TYPES AND SOURCES OF DATA}

The data used in this study are primary data obtained from the field through interviews using questionnaires. And secondary data is derived from sources from the publication of the Badan
Pusat Statistik (BPS) Humbang Hasundutan, the results of research, journals and other official publications.

\section{DATA ANALYSIS METHOD}

The analytical method used in this study are;

a) To determine the efficiency of paddy rice farming and livestock buffaloes in system integration and non integration in Humbang Hasudutan Regency, analyzed by models R/Cratio, with criterion $\mathrm{R} / \mathrm{C}>1$; farming is feasible, $\mathrm{R} / \mathrm{C}=1$; BEP (break-even point) and $\mathrm{R} / \mathrm{C}<1$; farming is not feasible.

b) To analyze the influence of physical factors; land are, paddy rice seeds, livestock breeds, livestock feed, fertilizer and pesticide in the system integration paddy rice and livestock buffaloes to the regional development in Humbang Hasundutan used multiple linear regression analysis, with the formula:

$Y=a+\beta_{1} X_{1}+\beta_{2} X_{2}+\beta_{3} X_{3}+\beta_{4} X_{4} \beta_{5} X_{5+}$

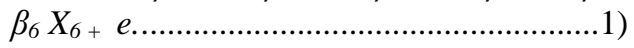

$\mathrm{Y}=$ Regional development with

indicators of farmers' income in system integration of paddy rice and buffaloes.

$\mathrm{a}=$ constant

$\mathrm{X} 1$ = land area

$\mathrm{X} 2$ = paddy rice seed

$\mathrm{X} 3=$ livestock breeds

$\mathrm{X} 4$ = livestock feed

$\mathrm{X} 5=$ paddy rice fertilizer

$\mathrm{X} 6=$ pesticide

$\mathrm{e}=$ error term

c) To analyze the influence of social factors; labor, education of farmer, dependent of farmers in system integration paddy rice farming and livestock buffaloes to the regional development in Humbang Hasundutan, used multiple linear regression analysis, with the formula:

$Y=a+\beta_{1} X_{1}+\beta_{2} X_{2}+\beta_{3} X_{3}+$ e....................................................2)

$\mathrm{Y}=$ Regional development with indicators of farmers' income in system integration of paddy rice and buffaloes.

$\mathrm{a}=$ constant

$\mathrm{X} 1$ = labor

$\mathrm{X} 2$ = education of farmers

$\mathrm{X} 3=$ dependent of farmers

$\mathrm{e}=$ error term

d) To analyze the influence of economic factors; farm capital, input prices, output prices of paddy rice farming and livestock buffaloes in systems integration to the regional development of Humbang Hasundutan used multiple linear regression formulae: $Y=a+\beta_{1} X_{1}+\beta_{2} X_{2}+\beta_{3} X_{3}+$ e........................................................ 3 ) 
$\mathrm{Y}=$ Regional development with indicators of farmers' income in system integration of paddy rice and buffaloes.

$\mathrm{a}=$ constant

$\mathrm{X} 1$ = capital of farming

$\mathrm{X} 2=$ input prices

$\mathrm{X} 3$ = output prices

$\mathrm{e}=$ error term

\section{RESULTS AND DISCUSSION}

The Level of Efficiency System Integration Paddy Rice Farming and Livestock Buffaloes in Humbang Hasudutan

Cost of Production Paddy Rice Farming and Livestock Buffaloes In System Integration

The total cost of production is the sum of the factors of production used in paddy rice farming and livestock buffaloes in one year, which includes variable cost and fixed cost. The cost of production paddy rice farming and livestock buffaloes in Humbang Hasundutan Regency as in Table 1.

Table 1. The Cost of Production Paddy Rice Farming and Livestock Buffaloes in Humbang Hasundutan.

\begin{tabular}{lccccc}
\hline Component & $\begin{array}{c}\text { Paddy rice } \\
\text { farming/ ha/ year } \\
(\mathrm{Rp})\end{array}$ & $\begin{array}{c}\text { Livestock } \\
\text { buffalo/ year } \\
(\mathrm{Rp})\end{array}$ & $\begin{array}{c}\text { Non integration (paddy } \\
\text { rice + livestock) } \\
\text { farmers/ year (Rp) }\end{array}$ & $\begin{array}{c}\text { Paddy rice and Livestock } \\
\text { buffaloes In systems } \\
\text { integration/ year (Rp) }\end{array}$ & $\begin{array}{c}\text { \% Cost rasio of } \\
\text { Integration and non } \\
\text { integration farming }\end{array}$ \\
\hline Fixed Cost (Rp) & $5.428 .199,30$ & $4.710 .500,00$ & $10.138 .699,30$ & $7.110 .959,44$ & 0,7014 \\
Variable Cost (Rp) & $2.493 .217,40$ & $5.431 .333,30$ & $7.924 .550,70$ & $6.369 .640,56$ & 0,8038 \\
Total cost (Rp) & $7.921 .416,70$ & $10.141 .833,30$ & $18.063 .250,00$ & $13.480 .600,00$ & 0,7463 \\
\hline
\end{tabular}

Sources: Primary data, processed in 2016.

Based on the results of data processing as well as in Table 1 it can be seen that the average total cost for the farming of paddy rice is Rp. 7, $921,416.70$ per ha per year and the average total cost of livestock buffaloes is Rp. 10,141,833.30 per year. If farmers manage the farm with the system integration between paddy rice and livestock buffaloes, the average total cost paid by farmers is Rp. $13,480,600.00$ per year and if the farmers manage non-integration of farming the farmer will have to pay Rp. 18.063.250,00 per year for paddy rice farming and livestock with a household scale. This means farming systems integration can save farmers' production costs incurred for each year indicated by the cost ratio between the integrated farming system (IFS) with non-integration farming of 0.7463 .

Revenue, Farmer Incomes, and Level of Efficiency Paddy Rice Farming and Livestock Buffaloes in System Integration
Soekartawi (2006) convey revenue is the total value of production by operating activities multiplied by the price. Revenue of farmers depends on the amount of production and the selling price. Farmers' income is the result of a reduction revenue to the cost of factors of production incurred by farmers. Production sector is the utilization factors of production used as inputs for farm production process (Sofyan, 2007).

The efficiency of farming is an attempt to achieve the goal by using the business production factor in minimal. Efficiency is the ratio between the cost of production with the output. If the result of farming farmers revenue is greater than the cost will reflect a good ratio and if the higher this value, the farm will be more efficient.

Based on analysis of the data result; revenue, farmers' income and the level of efficiency of paddy rice farming and livestock buffaloes in system integration in Humbang Hasundutan Regency as in Table 2.

Table 2. Revenue, Income of Farmers and Level of Efficiency of Paddy Rice Farming and Livestock Buffaloes in System Integration in Humbang Hasundutan Regency.

\begin{tabular}{lrrrrr}
\hline \multicolumn{1}{c}{ Component } & Revenue (Rp) & Total Cost (Rp) & $\begin{array}{c}\text { Income of } \\
\text { farmers (Rp) }\end{array}$ & R/C Ratio \\
\hline Paddy rice farming & $23.323 .000,00$ & $7.921 .416,70$ & $15.401 .583,30$ & 2,9443 \\
Livestock buffalo & $22.882 .534,25$ & $10.141 .833,30$ & $12.740 .700,95$ & 2,2563 \\
Paddy rice and livestock buffalo integration farming & $33.425 .540,00$ & $13.480 .600,00$ & $19.944 .940,00$ & 2,4795 \\
Non integration (paddy rice and livestock ) & $39.205 .533,35$ & $18.063 .250,00$ & $21.142 .283,35$ & 2,1705 \\
\hline
\end{tabular}

Sources: Primary data, processed in 2016.

Based on the analysis of data, as in Table 2 result that the average revenue of farmer from paddy rice farming Rp. 23,323,000.00 per ha/year, and buffaloes Rp. 22,882,534.25 per year. Then the average revenue farmers for paddy rice and livestock buffaloes in systems integration is Rp. $33,425,540.00$ per year while the revenue farmers 
with non-integration are Rp. 39,205,533.35 per year.

The average total cost of paddy rice farming Rp. 7.921.416.70 per ha per year, livestock buffaloes is Rp. 10,141,833.30 per year. For farming integration paddy rice and livestock buffaloes are Rp. 13,480,600.00 per year and average total cost of farming non-integration are Rp. 18.063.250,00 per year derived from paddy rice and livestock.

Based on the analysis of data, as in Table 2 also result that the average income of farmers for paddy rice farming Rp. $15,401,583.30$ per ha per year with $\mathrm{R} / \mathrm{C}$ ratio of 2.9443 . The revenue of the livestock buffaloes is Rp. 12,740,700.95 with $\mathrm{R} / \mathrm{C}$ ratio of 2.2563 . Then the average income of farmers with system integration paddy rice farming and livestock buffaloes is $\mathrm{Rp}$. $19,944,940.00$ per year with R/C ratio of 2.4795 . Furthermore, the average income of farmers with integration farming is Rp. 21,063,250.35 per year with a value of $\mathrm{R} / \mathrm{C}$ ratio of 2.1705 .

Thus if it is seen by the $\mathrm{R} / \mathrm{C}$ ratio of the paddy rice farming is still more efficient than livestock farming, which is indicated by the value of $\mathrm{R} / \mathrm{C}$ ratio of paddy rice farming $2.9443>$ of the value of the $\mathrm{R} / \mathrm{C}$ ratio of buffaloes livestock is 2.2563. And within their data processing results as in Table 2 indicate that in Humbang Hasundutan
Regency, system integration paddy rice and livestock buffaloes are more efficient than if the farm is managed non-integration farming, which is indicated by the value of $\mathrm{R} / \mathrm{C}$ ratio systems integration paddy rice farming and livestock buffaloes $2.4795>$ of the value of the $\mathrm{R} / \mathrm{C}$ ratio non-integration farming is 2.1705 .

\section{Influence of Physical Factors System Integration Paddy Rice Farming and Livestock Buffaloes to Regional Development in Humbang Hasundutan}

Rustiadi (2011) said one of the indicators of regional development based on the development process is income. Regional development in Humbang Hasundutan Regency in the context of the integrated farming system (IFS) is the use of parameters farmers' income. Farmers' income is influenced by many factors which are categorized into physical, social and economic among others; land area, rice production, the use of labor, the use of seed capital, fertilizers, pesticide for paddy rice farming and livestock feeds.

Based on the results of data analysis known physical factors of paddy rice farming and livestock buffaloes in integrated farming systems to the regional development in Humbang Hasundutan, as in Table 3.

Table 3. Results of the analysis of the influence of physical factors of paddy rice farming and livestock buffaloes in the system integration to the regional development in Humbang Hasundutan Regency.

\begin{tabular}{llcccc}
\hline No & Variable & Coefficients & $\mathrm{t}$ & Sig & $\begin{array}{c}\text { Adjusted R- } \\
\text { squared }\end{array}$ \\
\hline 1. & Intersep & 781,4 & & 0.948 \\
& X1 (land area) & $0,487^{*}$ & 11,431 & 0,02 & \\
X2 (paddy rice seeds) & 0,535 & 6,154 & 0,80 & \\
X3 (livestock breeds) & $0,155^{*}$ & 12,235 & 0,01 & \\
X4 (livestock feed) & $0,289^{*}$ & 10,124 & 0,03 & \\
X5 (paddy rice fertilizer) & 0,785 & 9,518 & 0,85 & \\
X6 (pesticide) & 0,837 & 8,965 & 0,99 \\
\hline
\end{tabular}

\section{Notes: $*$ significant at $\alpha=5 \%$}

The results of the analysis of data as in Table 3 obtained regression model as follows: $\mathrm{Y}=781.4+0,487 \mathrm{X} 1+0,535 \mathrm{X} 2+0,155 \mathrm{X} 3+$ $0,289 \times 4+0,785 \times 5+0,837 X 6$.

Results showed data analysts adjusted $\mathrm{R}^{2}$ value of 0.948 means that $94.8 \%$ of independent variables affect to dependent variable, in the sense of the variable land area, paddy rice seeds, livestock breed, livestock feed, fertilizer, and pesticide give the effect of $94.8 \%$ to the regional development in Humbang Hasundutan Regency seen from the level of farmers' income and the remaining $5.2 \%$ due to other factors beyond the variables to be estimated.

Based on the analysis of data as in Table 3 is result that the variable of land area has a positive effect with the coefficient of 0.487 and significant at $\alpha=5 \%$, with a value of $0.02 \mathrm{t}$ sig to the regional development in Humbang Hasundutan Regency, meaning that if the land area that is managed by farmers increasing the income of farmers in systems integration farming will increase, thus increasing income, illustrate the regional development in the region, as submitted Rustiadi, (2011) which states that one of the indicators of regional development based on the development process is revenue.

Then based on the analysis of data as in Table 3, that variable livestock breeds have a positive and significant impact to regional development in Humbang Hasundutan with coefficient 0.155 and significant at $\alpha=5 \%$, with a 
value of $\mathrm{t}$ sig 0.01 , meaning that if the livestock breeds available and at an affordable price farmers in Humbang Hasundutan it will impact on increasing the income of farmers which describes to regional development in the region.

Then variable livestock feed significant and positive impact to regional development, which is based on the level of significance result variable livestock feed has a coefficient of 0.289 and significant at $\alpha=5 \%$, with a value of $0.03 \mathrm{t}$ sig to regional development, where if livestock feed is available with both the will have an impact on increasing the income of farmers in the system integration, increase the income of farmers, emphasizing the regional development in Humbang Hasundutan.

Influence of Social Factors in Systems Integration Paddy Rice Farming and Livestock Buffalo to The Regional Development in Humbang Hasundutan

Based on the results of data analysis known social factors paddy rice farming and livestock buffaloes in system integrated to the regional development in Humbang Hasundutan as in Table 4.

Table 4. Results of the analysis of the influence of social factors paddy rice farming and livestock buffaloes in the system integration to the regional development in Humbang Hasundutan Regency.

\begin{tabular}{clcccc}
\hline No & Variable & Coefficients & $\mathrm{t}$ & Sig & $\begin{array}{c}\text { Adjusted R- } \\
\text { squared }\end{array}$ \\
\hline 1. & Intersep & 527,8 & & 0.968 \\
& X1 (labour) & $0,765^{*}$ & 12,553 & 0,03 & \\
& X2 (education of farmer) & $0,886^{*}$ & 11,345 & 0,04 & \\
X3 (dependent of farmers) & $-0,650$ & 8,234 & 0,08 & \\
\hline
\end{tabular}

Notes: * significant at $\alpha=5 \%$

Based on the analysis of data as in Table 4 was obtained regression model as follows: $\mathrm{Y}=527.8+0,765 \mathrm{X} 1+0,886 \mathrm{X} 2-0,650 \mathrm{X} 3$

Results showed data analysts adjusted $\mathrm{R}^{2}$ value of 0.968 means that $96.8 \%$ of independent variables such as variable labor, education of farmers, dependent of farmers influence to the regional development in Humbang Hasundutan seen from the level of farmers' income and the remaining $3.2 \%$ due to factors other than the variable to be estimated.

Based on the analysis of data as in Table 4 result variable labour has a positive effect with the coefficient of 0.765 and significant at $\alpha=5 \%$, with a value of $0.03 \mathrm{t}$ sig to the regional development in Humbang Hasundutan Regency, this can be interpreted if the labour available well then it will have an impact on regional development that can be seen from the increase in the income of farmers in Humbang Hasundutan, according to research results Tarmizi (2012) which states that the integrated system of paddy rice and livestock has a positive impact on regional development in Serdang Bedagai, which indicated by the increase in paddy rice production in integrated farming system (IFS) and increased use of labor in the family.
Then the variable education of farmers is also positive and significant impact on regional development in Humbang Hasundutan, as indicated by the coefficient of 0.886 and significant at $\alpha=5 \%$, with a value of t sig 0.04 , meaning that if the level of education of farmers getting better will positively affect the regional development marked by the increasing income of farmers in Humbang Hasundutan Regency. Then the social variable dependents of farmers have a negative effect to the regional development of the area, but not significant with coefficient -0.650 , meaning that if the dependents of farmers are increasing, then it will not have a negative impact on the regional development Humbang Hasundutan Regency.

Influence of Economic Factors Integration Paddy Rice Farming and Livestock Buffaloes in System Integration to Regional Development in Humbang Hasundutan Regency

Based on the results of data analysis known economic factors paddy rice and livestock buffaloes in system integrated on regional development in Humbang Hasundutan as in Table 5. 
Table 5. The results of the analysis of the influence of economic factors paddy rice and livestock buffaloes in system integration to the regional development in Humbang Hasundutan Regency.

\begin{tabular}{llcccc}
\hline No & Variable & Coefficients & $\mathrm{t}$ & $\mathrm{Sig}$ & $\begin{array}{c}\text { Adjusted R- } \\
\text { squared }\end{array}$ \\
\hline 1. & Intersep & 567,6 & & - & 0.958 \\
& X1 (capital of farming) & $0,870^{*}$ & 13,359 & 0,03 & \\
& X2 (input prices) & $-0,543$ & 7,876 & 0,09 & \\
X3 (ouput prces) & $0,876^{*}$ & 10,393 & 0,04 & \\
\hline
\end{tabular}

Notes: * significant at $\alpha=5 \%=0.05$

The results of the analysis of data as in Table 5 is obtained regression model as follows: $\mathrm{Y}=567.6+0,870 \mathrm{X} 1-0,543 \mathrm{X} 2+0.876 \mathrm{X} 3$

Results showed data analysts adjusted $\mathrm{R}^{2}$ value of 0.958 means that $95.8 \%$ of the variable capital of farming, input prices, output prices to give effect to the regional development in Humbang Hasundutan seen from the level of farmers' income, the rest of $4.20 \%$ due to other factors which are not included in the estimation.

Based on the analysis of data as in Table 5 result the variable capital of farmers has a positive effect with the coefficient of 0.870 and significant at $\alpha=5 \%$, with a value of $0.03 \mathrm{t}$ sig to the regional development as seen from the income level of farmers in systems integration in Humbang Hasundutan Regency, meaning that if the capital of farming increase will have a positive impact for the regional development an indicated by the increased incomes, system integration paddy rice and livestock buffaloes in Humbang Hasundutan Regency.

Then the variable input prices has a negative influence but not significant to the regional development in Humbang Hasundutan, as indicated by the coefficient of -0.543 , meaning that if the price of inputs, in this case, the price of fertilizers, pesticide, seed and feed increases than will impact on the level the income of farmers in the paddy rice farming and livestock buffaloes in system integration in Humbang Hasundutan Regency.

Meanwhile output prices have a positive impact and significantly to the regional development as seen from the level of farmers' income, and based on the level of significance is unknown output price variable has a coefficient of 0.876 and significant at $\alpha=5 \%$, with a value of $0.04 \mathrm{t} \mathrm{sig}$ to the regional development, meaning the price output, in this case, the price of grain, buffalo selling price, the price of meat and buffalo milk price increases then the income level of farmers in systems integration will increase which also depicts the regional development in Humbang Hasundutan Regency.

\section{CONCLUSIONS}

Based on the results of data processing and discussion that done, so the conclusions that can be drawn is:

1. System integration paddy rice and livestock buffaloes in Humbang Hasundutan more efficient than the non-integration, which is indicated by the value of $\mathrm{R} / \mathrm{C}$ ratio of paddy rice in systems integration with livestock buffaloes is $2.4795>$ of the value of the R/C ratio of non-integration with value 2.1705 .

2. Physical factors such as variable systems integration; land area, livestock seeds and livestock seeds have a positive and significant impact on the regional development in Humbang Hasundutan Regency.

3. Social factors such as variable farming systems integration; labor and education of farmers have a positive effect and significant to the regional development, while that dependent of farmers as social variables has the negative effect to regional development in Humbang Hasundutan Regency.

4. Economic factors such as variable farming systems integration; capital of farmers and output prices have as positive effect and significant to the regional development, while the economic variable input prices have negatively affect to the development in Humbang Hasundutan Regency.

\section{RECOMMENDATIONS}

Based on the results of data processing and the discussion that has been done, it is recommended:

1. For the government, Humbang Hasundutan must conduct training the farmers in managing their farms in system integration between paddy rice farming and livestock.

2. The government of Humbang Hasundutan should play a role provide quality seed and affordable for farmers, in addition to the necessary counseling for farmers or ranchers about how to be a goog farming.

3. The government of Humbang Hasundutan should provide education and training to 
improve traffic farmers in managing and developing farming that have an impact on increasing the income of farmers and development farming wich increased to regional development in Humbang Hasundutan Regency.

4. For the government of Humbang Hasundutan role in helping farmers to obtain capital more flexible farming and the government is also expected to contribute to maintaining price stability in the output of agricultural products in Humbang Hasundutan Regency.

\section{ACKNOWLEDGEMENTS}

Thanks to LPDP Kementerian Keuangan Republik Indonesia acknowledged for supporting this research.

\section{REFERENCES}

Agus, C. 2006. Integrated Farming System In Agricultural Training, Research, and Development Centre (ATRDC) UGM. Proceeding of International Seminar on Agroforestry. Jogyakarta. INAFE and UGM.

Boix, R, L and Zinck A, J. 2008. Land-Use Planning in the Chaco Plain (Burruyacu, Argentina). Part 1: Evaluating Land-Use Options to Support Crop Diversification in an Agricultural Frontier Area Using Physical Land Evaluation. Journal Springer.

BPS, Kabupaten Humbang Hasundutan Dalam Angka 2015. Doloksanggul.

BPS, Kabupaten Humbang Hasundutan Dalam Angka 2014. Doloksanggul.

BPS, Kabupaten Humbang Hasundutan Dalam Angka 2010. Doloksanggul.

BPS, Propinsi Sumatera Utara Dalam Angka 2014. Medan.

Diabel, W, M, Maxted T, J, Robertson, M, D, Han, S and Zanden, M.J.V. 2008. Landscape Planning for Agricultural Nonpoint Source Pollution Reduction III: Assessing Phosphorus and Sediment Reduction Potential. Journal Springer.

Elizabeth, R dan Darwis, V. 2003. Karakteristik Petani Miskin dan Persepsinya Terhadap Program JPS di Propinsi Jawa Timur. Jurnal SOCA. Bali.

Juangsana, Hang Hendra, 2013. Strategi Pengembangan Agribisnis Komoditas Cengkeh Dalam Meningkatkan Pendapatan Petani di Kabupaten Trenggalek. Jurnal Manajemen Agribisnis. Vol. 13.No.2

Nainggolan, Hotden, Sihombing, Marlon, Supriana Tavi, Tafsin Ma'aruf. 2016. Integrated Farming System on Paddy Rice in The Framework for Regional Development in
District of Lintong Nihuta Humbang Hasundutan Regency. Proceeding International Converence of Computers, Environment, Social Science, Enginering and Technology (ICEST) 2016. Medan. Indonesia.

Nurcholis, M dan Supangkat, G. 2011. Pengembangan Integrated Farming System Untuk Pengendalian Alih Fungsi Lahan Pertanian. Prosiding. Seminar Nasional Budidaya Pertanian, Urgensi dan Strategi Pengendalian Alih Fungsi Lahan Pertanian. Bengkulu.

Preston, T.R. 2000. Livestock Production from Local Resources in an Integrated Farming System; a Sustainable Alternative for the Benefit of Small Scale Farmers and the Environment. Workshop-seminar "Making better use of local feed resources" SARECUAF.

Riyadi dan Bratakusumah, D. S. 2003. Perencanaan Pembangunan Daerah. Startegi menggali Potensi Dalam Mewujudkan Otonomi Daerah. Gramedia Pustaka Utama. Jakarta.

Rustiadi, Ernan; Saefulhakim, Sunsun dan Dyah R. Panuju. 2011. Perencanaan dan Pengembangan Wilayah. Jakarta: Crestpent Pres dan Yayasan Pustaka Obor Indonesia.

Salikin, Karwan. A. 2003. Sistem Pertanian Berkelanjutan. Yogyakarta: Kanisius.

Setyowati, Nuning. 2012. Analisis Peran Sektor Pertanian di Kabupaten Sukoharjo. Jurnal SEPA: Vol. 8 No. 2.

Soekartawi. 2006. Analisis Usaha Tani. Cetakan Ketujuh. Jakarta: Universitas Indonesia Press.

Sofyan, A. 2007. Teori Ekonomi Mikro. Edisi Kedua. Cetakan Kelima. Bogor: Institut Pertanian Bogor.

Sugiyono. 2006. Metode Penelitian Administrasi. Edisi XII. Bandung: Alfabeta.

Supangkat, G. 2009. Sistem Usaha Tani Terpadu, Keunggulan dan Pengembangannya. Workshop Pengembangan Sistem Pertanian Terpadu. Yogyakarta: Dinas Pertanian Provinsi Daerah Istimewa Yogyakarta.

Sutanto, R. 2002. Penerapan Pertanian Organik. Permasyarakatan dan Pengembangannya. Yogyakarta: Penerbit Kanisius.

Tarmizi, Hasan Basri dan Safaruddin, 2012. Pengaruh Sistem Integrasi Padi Ternak (SIPT) Terhadap Peningkatan Pendapatan Petani Dan Dampaknya Terhadap Pengembangan Wilayah Di Kabupaten Serdang Bedagai. Jurnal Ekonom, Vol 15, No 4.

Ugwumba, C.O.A, Okoh, R.N, Ike, P. C, Nuabuife, E.L.C, and Orji, E.C. 2010. Integrated Farming System and Its Effect on 
Farm Cash Income in Awka South Agricultural Zone of Anambra State Nigeria. American-Eurasian Journal Agricultural and Environment Science. Vol 8 (1).

Yanti, Sri Novi, Salmiah, Kusuma, Indra Sinar. 2010. Strategi Peningkatan Pendapatan Petani Padi Organik (Studi Kasus: Desa Lubuk Bayas, Kecamatan Perbaungan. Kabupaten Serdang Bedagai). Hasil Penelitian. Medan: Program Studi Agribisnis. Fakultas Pertanian. Universitas Sumatera Utara. 